\title{
Pastors as gewonde genesers: Outobiografiese pastoraAt as HEELMIDDEL VIR EMOSIONELE VERWONDING EN VERLAMMING BY PASTORS
}

\author{
Authors: \\ S. Phillip Nolte ${ }^{1}$ \\ Yolanda Dreyer
}

\section{Affiliations: \\ ${ }^{1}$ Departement Praktiese Teologie, Fakulteit Teologie, Universiteit van Pretoria, Suid-Afrika}

\section{Correspondence to: S. Phillip Nolte}

e-mail:

pnolte@vodamail.co.za

\section{Postal address:}

Posbus 2433, Montanapark, 0159, Suid-Afrika

\section{Keywords:}

pastors; kognitiewe dissonansie; paradigma; postmodern; teologies

\section{Dates:}

Received: 02 Feb. 2009

Accepted: 26 Mar. 2009

Published: 25 June 2009

How to cite this article: Notle, S.P. \& Dreyer, Y., 2009, 'Pastors as gewonde genesers: Outobiografiese pastoraat as heelmiddel vir emosionele verwonding en verlamming by pastors', HTS Teologiese Studies/Theological Studies 65(1), Art. \#158, 9 pages. DOI: $10.4102 /$ hts. v65i1.158

\section{This article is available} http://www.hts.org.za
(C) 2009. The Authors. Licensee: OpenJournals Publishing. This work is licensed under the Creative Commons Attribution License.

\section{ABSTRACT}

Pastors as wounded healers: Autobiographical pastorate as a way for pastors to achieve emotional wholeness

In a previous article it was argued that pastors suffer from cognitive dissonance because of the paradigm shift from modernity to postmodernity, and the emotional woundedness that frequently results from their struggles to come to terms with the new world in which they have to live and minister. This article reflects on the way in which two further issues may exacerbate emotional woundedness in pastors. The one is church tradition, as it is reflected in several formularies used during church services in the Nederduitsch Hervormde Kerk van Afrika (NHKA), as well as the Church Ordinance of the NHKA. The other issue is the way in which pastors view the Bible. The language and rhetoric used to reflect on these issues are discussed and evaluated. In its last paragraph the article reflects on the possibility of autobiographical pastorate as a way for pastors to achieve emotional wholeness.

\section{INLEIDING}

In 'n vorige artikel (Nolte \& Dreyer 2008:1005-1020) is aangevoer dat pastors kognitiewe strydigheid ervaar as gevolg van die oorgang van 'n moderne na 'n postmoderne paradigma. Die postmoderne paradigma behels onder andere dat godsdienstige sekerhede van die verlede gerelativeer word, wat op sy beurt ook die Skrifbeskouing, Skrifgesag en kerklike tradisies in gedrang bring. Menige pastors bevind hulle in 'n moderne paradigma, oortuig dat die Bybel en teologiese tradisie 'voldoende antwoorde' op hedendaagse vrae en uitdagings bied. Die mense vir wie hulle bedien, leef egter in 'n postmoderne kultuur wat die aanname dat die Bybel en belydenisskrifte as 'norm' vir mense se verhouding met God, en vir hulle geloof en lewens behoort te geld, op vele wyses bevraagteken. Dié dilemma kom op minstens twee vlakke tot uiting. Aan die een kant is daar lidmate wat hulleop religieuse vlak reeds in die postmoderne paradigma bevind, terwyl hulle pastors en geloofsgemeenskap(pe) nog vanuit die moderne paradigma funksioneer. Aan die ander kant is daar pastors wat hulle teologies en filosofies in die postmoderne paradigma bevind, terwyl hulle geloofsgemeenskap(pe) nog in 'n moderne paradigma verkeer.

Pastors wat vanuit die opkomende, postmoderne paradigma dink en funksioneer, kan spanning ervaar wanneer daar oor temas soos Skrifgesag, die funksie van kerklike belydenisse, die maagdelike verwekking van Jesus, Jesus se opwekking uit die dood, sowel as oor sake soos homoseksualiteit, die toelating van vroue tot kerklike ampte, en die vraag oor watter godsdiens 'die ware godsdiens' is, besin word. Malherbe en Louw, (2002:519; kyk ook Burton 1988:46-60), is van mening dat 'n paradigma van onderhandeling ('negotiation') moderniteit en postmoderniteit moontlik kan kombineer sodat bediening in 'n pluralistiese samelewing doeltreffender kan wees. Of dit haalbaar is, bly egter 'n ope vraag, aangesien verskillende paradigmas moeilik met mekaar versoen word (kyk Kuhn 1970:160-173). Hierdie artikel besin verder oor dié saak, met 'n bepaalde fokus op die wyse waarop kerklike tradisie en Skrifgesag tot 'verwonding' en 'verlamming' by pastors bydra. Aan die einde van die artikel word 'outobiografiese pastoraat' as weg tot heling beredeneer.

\section{DIE KERKLIKE TRADISIE AS STRUIKELBLOK}

Die moontlikheid van emosionele genesing, en die vraag of dit wel haalbaar is, word deur bepaalde kerklike tradisies met betrekking tot die amp van predikant belemmer. Dít blyk duidelik uit formulerings oor dié amp in die Kerkorde van die Nederduitsch Hervormde Kerk van Afrika (Nederduitsch Hervormde Kerk van Afrika/NHKA. 67e Algemene Kerkvergadering. [S.a]. Kerkorde van die Nederduitsch Hervormde Kerk van Afrika sowel as die bevestigingsformulier vir predikante. Ordereël 2 in voormelde kerkorde (NHKA [S.a.]:6-7) beskryf predikante as 'dienaars van die Woord' met die voorreg van 'Woordverkondiging en sakramentsbediening'. Wanneer daar oor 'predikante in gemeentes' gepraat word, word predikante se dienswerk met sewe kort sinsnedes omskryf, met 'herderlike sorg' as een daarvan. Die res fokus op Woordverkondiging en die toerus van lidmate. In ordinansie 2.1.5 (NHKA [S.a.]:24-25) word predikante se gemeentelike arbeid deur negentien frases beskryf, waarvan drie op een of ander wyse na 'herderlike versorging' verwys. Die huidige formulier vir die bevestiging van 'dienaars van die Goddelike Woord' in hulle ampte (Diensboek van die Nederduitsch Hervormde Kerk van Afrika/NHKA 1997:75-78), beskryf predikante as 'herders en leraars' wat oor 'God se kudde' aangestel is met die doel om die 'kudde' met die Goddelike Woord as staf te lei en regeer (Diensboek van die NHKA 1997:75). Die predikantsamp word as 'die amp van herder en leraar' (Diensboek van die NHKA 1997:75) geformuleer, en predikante word aangemoedig om 'die goeie dissipline te handhaaf en die gemeente ordelik te regeer, soos die Here dit voorgeskryf het' (Diensboek van die NHKA 1997:76).

Op hierdie wyse word nie net die 'amp van predikant' as 'n goddelike gawe gelegitimeer nie, maar ook die wyse waarop predikante hulle werk moet benader, naamlik om 'te regeer' en 'dissipline uit te oefen' oor ander mense met die oog daarop om 'ordelik te regeer', want dit is 'hoe die Here dit voorgeskryf het.' Hierdie soort taal skep en handhaaf 'n verhouding van outoritêre gesag oor mense, en sodoende verskerp die herder- en leraarkonsep onderlinge ongelykheid. Die formulier beskou pastors as leraars en herders wat deur God gegee is, sodat mense deur middel van die regte dissipline en beheer op God se pad gehou kan word. 
Dit is egter opvallend dat daar in die woorde van die formulier wat persoonlik tot die predikant gerig word geen melding van 'regering' gemaak word nie, maar dat ' $n$ 'sagter' benadering hier aangetref word. Die Diensboek van die Nederduitsch Hervormde Kerk van Afrika lui in dié verband soos volg:

U moet Christus liefhê en as herder sy skape versorg deur oor hulle toesig te hou, nie uit dwang nie, maar gewillig; nie om eie gewin nie, maar met toewyding (1 Pet 5:2); ook nie deur baas te speel oor dié wat God aan u sorg toevertrou het nie, maar deur'n voorbeeld vir die kudde te wees.

(Diensboek van die NHKA 1997:77)

Die NHKA se formulier vir die bevestiging van ouderlinge en diakens benader egter die ouderlingamp vanuit 'n outoritêre posisie as ' $n$ 'aansienlike regeeramp' (Diensboek van die NHKA 1997:79). Deur die amp van ouderling aan die 'Ou Verbond' te koppel, word daar aan die hand gedoen dat hierdie soort leierskap in die Ou Testament aangetref word, en dat dit dus deur God erken is. Die formulier stel dit dan ook dat die ouderlinge saam met die 'dienaars van die Woord mederegeerders' is en dat hulle:

... saam met die dienaars van die Woord opsig hou oor die gemeente wat aan hulle toevertrou is. Dit moet hulle doen deur noulettend toe te sien dat elkeen hom en haar in belydenis betaamlik gedra, die onordelikes te vermaan en om sover moontlik te verhoed dat die sakramente ontheilig word. Verder moet hulle volgens die bepalings van die kerklike tug optree teen dié wat nie berou toon nie en dié wat berou toon, weer in die gemeenskap van die kerk opneem.

(Diensboek van die NHKA 1997:79; eie beklemtoning)

Hierdie amptelike dokumente van die NHKA handel nie oor predikante as pastors nie; pastors (en ouderlinge) se regerings-, opsig- en tugbevoegdhede word eerder beklemtoon. Daar kan aanvaar word dat ' $n$ kerk se teologiese besinning in sy kerkorde en bevestigingsformuliere geopenbaar word. In die NHKA se geval is ' $n$ outoritêre beskouing oor gesag in genoemde dokumente sigbaar. Die wyse waarop die Bybel in voormelde formuliere aangewend word, weerspieël 'n logies-positivistiese denkmodel waarvolgens daar op induktiewe wyse (kyk Mouton 1987:1-29) met behulp van 'n veelheid van tekste algemene afleidings oor die predikantsamp gemaak word. Dit is egter belangrik om te meld dat die NHKA tans besig is om al hulle formuliere op teologiese en kommunikatiewe vlak te ondersoek en te herskryf.

Bogenoemde teologiese uitgangspunte met betrekking tot die beskouing oor die amp van predikant gee aanleiding tot ' $n$ struktuur waarin magsposisies aan predikante (en ouderlinge) toegeken word. Indien pastors hierdie beskouings aanvaar en dit hulle eie maak, kan dit die moontlikheid van emosionele transformasie belemmer, en tot teologiese stagnasie aanleiding gee. Persone wat nie op kognitiewe en emosionele vlak uitgedaag word nie, of hulle nie op hierdie vlak láát uitdaag nie, kan nie tot selfinsig kom en sinvol transformeer nie. Besinning oor die formulerings in bogenoemde kerkorde en formuliere laat die volgende vrae na vore tree:

- Watter epistemologiese funksie of rol word in teologiese teorievorming oor die pastoraat aan die Bybel toegeken?

- Besin pastors doelbewus oor hulleself en hulle wisselwerking met mense?

- Op watter wyse beïnvloed eietydse filosofiese, sosiale, religieuse en psigologiese teorieë pastors se denke oor hulleself, hulle omgewing en hulle funksionering binne dié omgewing?

- Besef pastors dat hulle eie omgewings hulle teorieë en praktyke beïnvloed, en indien wel, op watter wyse word dit verreken?

- $\quad$ Bied die Reformatoriese teologie ruimte vir die insig dat pastors emosionele verwonding ervaar, en dat daardie verwonding nie ontken hoef te word nie, maar as bron van bemoedigende en sinvolle betrokkenheid by ander met dieselfde én ander soorte verwonding kan dien?
- Is dit moontlik dat pastors in 'n postmoderne kultuur waarde tot mense se lewens kan toevoeg? Indien wel, op watter wyse kan dit geskied?

In die laaste dekade van die vorige millennium het ingrypende paradigma verskuiwings in Suid-Afrika begin posvat, wat ook die kerklike toneel en die lewens en funksionering van pastors beïnvloed. Die oorgang van ' $n$ moderne na ' $n$ postmoderne samelewing noodsaak geloofsgemeenskappe en pastors om na te dink oor hoe hulle hulleself en die wêreld waarin hulle leef, vertolk. Christelike geloofsgemeenskappe en pastors vorm deel van kulturele groeperinge, en enige verandering in daardie kulturele groeperinge lei tot nuwe insigte oor die betekenis van teologie, Christenwees en pastorwees in veranderende omstandighede. Die filosoof, Deon Rossouw formuleer hierdie proses van voortdurende hervertolking soos volg:

The shift from a modern to a postmodern (or late-modern, as some prefer to call it) culture, obviously requires new theological reflection. This cultural shift, which is still in the making, brings a new understanding of self and the world with it

(Rossouw 1993:895)

\section{SKRIFGESAG AS PROBLEEM}

'n Postmoderne paradigma bring die besef dat daar nie meer soos in die moderne era oor waarheid, ${ }^{1}$ die Bybel, pastors se wisselwerking met mense, sowel as pastors se siening oor hulle posisie en funksionering in hulle geloofsgemeenskappe én in die groter gemeenskap gedink kan word nie. Pastors word op hierdie vlak in die besonder gedwing om van hulle beskouing oor waarheid - wat hulle Skrifbeskouing insluit - rekenskap te gee. Ontwikkelinge in die teologie sedert die 19de eeu kan die indruk by pastors wek dat die gesag van die Bybel, soos dit in belydenisskrifte verwoord is, aangetas word. Daarmee saam word die gronde vir hulle sekerheid oor God, en geloof en 'n Christelike lewenswyse weggekalwe. Die opkomende paradigma en die implikasies daarvan veroorsaak dat pastors, as gevolg van spanning tussen hulle geloof en wetenskaplike teologiese besinning, verlamming beleef. Die kritiese, wetenskaplike bestudering van die Bybel laat pastors met die vraag worstel of die Bybel dan nog enige waarde vir mense het as dit nie in sy geheel as 'God se Woord' beskou kan word nie. Edward Farley (1996:13-28) beskryf hierdie veranderinge as die erosie of dreinering van die betekenis van diepgewortelde simbole ('deep symbols').

In hierdie verband is dit belangrik om van Andries van Aarde (2001:148-171) se beredenering oor die Jesus-saak ('cause of Jesus') as 'die kanon agter die kanon' kennis te neem. Vir sy beredenering, wys Van Aarde (2001:149) daarop dat die uitdrukkings 'the cause of Jesus' en 'canon behind the canon' hulle ontstaan in die teologiese besinning van die Duitse NuweTestamentikus Willi Marxsen gehad het. Marxsen (Buswell 1968:284) voer aan dat die Nuwe Testament nie in die plek

\footnotetext{
1.Die transformasie met betrekking tot die begrip 'waarheid' word in die rapport van die Gereformeerde Kerken van Nederland, God met ons: ... over de aard van het Schriftgezag ... (Bearda t al. 1981) beskryf. Volgens 'n 'objektiewe' warheidsbeSchriftgezag ... (Baarda et al. 1981) beskryf. Volgens 'n 'objektiewe' waarheidsbegrip is die mens 'n passiewe waarnemer van 'objekte soos dit is',' en is menslike voorstellings korrekteweergawes van objekte wat butte die mens gelee is. Die voordeel van hierdie beskouing is dat waarheid aan " $n$ norm buite die mens verbin word; die nadeel is egter dat dit nie erkenning verleen aan wisselwerking tussen mense en objekte nie. Naas hierdie beskouing gee 'n 'subjektiewe' waarheidsbegrip ' $n$ prominente plek aan die denkarbeid en formuleringsvermoë van mense. Waarheid word deur die mens self bedink en voortgebring, en is hiervolgens nie in die 'objektiewe' stand van sake geleë nie, maar word op skeppende en daadwerklike wyse deur mense geskep. Die voordeel van hierdie beskouing is dat dit menslike aktiwiteit met betrekking tot die vertolking van die werklikheid met erns bejeën. Die nadeel is dat waarheid hiervolgens in die mens self geleë is, en dat dít tot subjektivisme kan lei. Die rapport kies egter ' $n$ ander teorie, naamlik ' $n$ 'relasionele waarheidsbegrip'. Hierdie beskouing van waarheid beklemtoon die verwantskap tussen subjek en objek - ' $n$ verwantskap tussen die mens as subjek, en dit wat buite die mens lê as objek. Hiermee word erken dat wetenskappe nie bloot 'dinge soos dit is' weerspiël nie, mar dat menslike vooroordele, teorië, ervarings en modelle di is 'weerspicel nie, maar dat menslike vooroordele, teoriee, ervarings en modelle die wyse waarop objekte besky ineenvelich plus het subjectieve in de mens (de waarheid als worsteling, als inzet van de mens)' (Baarda et al. 1981.12). Teologies beskou, beteken dit dat daar 'n verwantskap bestaan tussen God se openbaring (objektief, buite die mens) en die mens (ook die mens se besinning oor God as subjektiewe aktiwiteit)
} 
van Jesus as 'die openbaring' gestel behoort te word nie. Die 'Jesus-saak' gaan oor die wyse waarop die waardes van God se koninkryk in Jesus van Nasaret geopenbaar word. Hierdie waardes word gemotiveer deurdat mense hulle vertroue in God stel, weens die wyse waarop God in Jesus 'sigbaar' was. Hoewel die Bybel oor hierdie saak getuig, is die Christelike geloof nie 'n 'boekgeloof' nie, maar 'n geloof (godsdiens) waarvan die oorsprong in die verhouding met 'n geskiedkundige persoon, naamlik Jesus, lê. Van Aarde (2001:150) wys daarop dat geloof 'n saak van die hart sowel as van denke en dade is. Geloof ontstaan nie in die innerlike van mense sonder 'n oriënteringspunt wat buite mense lê nie. Volgens Van Aarde is dit:

...something 'out there' that has caused the Christian believer to put her or his ultimate trust in God's event through Jesus. Objectifying this cause, or articulating it in terms of faith assertions, is already the activity of head and hand.

(Van Aarde 2001:150)

Die objektivering van geloof het tot gevolg dat mense in leerstellings glo omdat dit 'die waarheid oor God en Jesus' sou wees. Die Bybel bevat 'n verskeidenheid standpunte oor wat waarheid is. Derhalwe is dit moeilik om van 'dié waarheid' te praat asof dit 'n een dimensionele begrip sou wees (Van Aarde 1999:11-19). Van Aarde (1999:19) blyk ten gunste van 'n relasionele waarheidsbegrip te wees, waarmee bedoel word dat waarheid nie in proposisies gevind word nie, maar in ' $n$ verhouding met God, oftewel die waarheid wat in Jesus is (Van Aarde 1999:19). Dit is in hulle ontmoeting met Jesus dat Christene God ontmoet het en steeds ontmoet. God is vandag vir mense God op grond van die bemiddeling van die geskiedkundige tekste wat in die Bybel aangetref word, maar God, en nie die Bybel nie, is vir Christene die hoofgesag. Van Aarde formuleer hierdie saak soos volg:

Die Christelike geloofsgemeenskap het wel belydenismatig ooreengekom dat sekere geskrifte (wat die kanon genoem word) die model vorm waar die Jesus-saak geloofwaardig betuig word, maar het nie daarmee besluit om enige getuienis oor die waarheid wat in Jesus is te objektiveer as dit waarin die mens moet glo nie. Ons glo in God en nie in die Bybel of enige na-Bybelse credo nie.

... Wanneer ' $n$ credo ' $n$ vaste, geykte belydenis met normatiewe binding los van tyd en kultuur geword het, het dit die vorm van dogma aangeneem

(Van Aarde 1999:19)

Dogmas word deur middel van proposisionele taal geformuleer, en het tot gevolg dat mense wat nie met bepaalde dogmas saamstem nie, as 'vrysinnig', 'liberaal' of 'ketters' gebrandmerk word. Dogmatiese taal kan manipuleer, marginaliseer en opponente uit die weg ruim (Van Aarde 1999:20). Indien mense dogmas as 'die waarheid' aanvaar en as 'die fondament' van hulle geloof beskou, beteken dit dat hulle geloof in der waarheid die geloof van ander is, naamlik die geloof van die persone wat die dogmas geformuleer het. Vanaf die vroegste tye in die Christelike geloofsgemeenskap is belydenisse oor Jesus uitgespreek, en was daar uiteenlopende menings en selfs diepgaande verskille oor navolging van Jesus (Van Aarde 2001:150-151). As gevolg van hierdie verskille het verskeie tekste ontstaan, maar slegs dié tekste wat aan bepaalde maatstawwe voldoen het, is in die Christelike kanon opgeneem. Een van die gevolge hiervan is dat Christene wat die moderne paradigma aanhang, in 'n groter mate 'in die Bybel glo' as in God, met die oortuiging dat, indien die Bybelse gegewens nie geskiedkundig korrek is nie, dit beteken dat God ook nie betroubaar is nie.

Van Aarde (2001:151) formuleer op genuanseerde wyse dat nadenke oor 'die Jesus-saak' as kanon agter die kanon die gesag van die Bybel relativeer, maar tog ook nie. Die relativering van die Skrifgesag is daarin geleë dat daar bewyse bestaan van hoe die konsep 'kanon' as magsinstrument aangewend word (kyk Altieri 1990; Ter Borg 1998:411-423; Chapman 2000:93-97). So 'n hantering van die Skrif strook egter nie met die geloof waarvan die Skrif getuig nie, en kan na die magsposisie van die Roomse kerk in die Weste teruggevoer word, asook die wyse waarop die
Romeinse keiser Konstantyn sy mag in die vierde eeu misbruik het om die kerk in 'n afgebakende kanon in te dwing (Van Aarde 2001:152). Aan die ander kant word die Skrifgesag ook nié gerelativeer nie, omdat besinning oor die status van die Bybel daardie aspek belig wat grondliggend is aan die gesag van die Bybel, wat volgens Van Aarde (2001:149; 153-160) die openbaring van God in Jesus van Nasaret is. Geloof is dus vertroue in God, op grond van die oortuiging dat God self in Jesus openbaar, en is ook 'n verbintenis tot die 'Jesus-saak'. In dié sin is geloof 'n voortdurende proses van ontmoeting met God in Jesus, en bly dit dus lewend.

Dit is in die gees van hierdie besinning dat pastors van hulle eie verwonding en verlamming bewus raak, omdat hulle in 'n geloofstradisie grootword wat hoofsaaklik op die aanvaarding en erkenning van dogmatiese proposisies oor God, Jesus Christus en die Bybel berus. Hierdie saak kom op verskeie wyses in die liturgiese formuliere van die NHKA na vore. In die 'formulier vir die bediening van die doop aan die kinders van gelowiges' word daar aan die dopeling se ouers gevra:

Bely $u$ ook dat die leer van die Ou en Nuwe Testament wat in ons belydenis saamgevat is en in die Kerk hier geleer word, die ware en volkome leer van die verlossing is?

(Diensboek van die NHKA 1997:53; eie beklemtoning)

In die 'formulier vir die bediening van die doop aan volwassenes' word die dopeling in die eerste vier van vyf vrae gevra of hy/ sy bepaalde sake 'glo', 'bely' en 'onderskryf' (Diensboek van die NHKA 1997:56-57). Al hierdie sake is temas wat as dogmas in die belydenisskrifte geformuleer is. Dieselfde geld die 'formulier vir die bevestiging van dienaars van die Goddelike Woord' wanneer daar aan die predikant gevra word: 'Glo $\mathrm{u}$ dat die $\mathrm{Ou}$ en Nuwe Testament die enigste Woord van God en die volkome leer van die redding is en verwerp $\mathrm{u}$ alle leringe wat daarmee in stryd is?' (Diensboek van die NHKA, 1997:77; eie beklemtoning; kyk ook Van Aarde, 1999:20 se insig dat dogmatiese taal kan manipuleer, marginaliseer en opponente uit die weg ruim), en 'Ten derde vra ek $\mathrm{u}$ of $\mathrm{u}$ beloof om $\mathrm{u}$ amp, soos dit hierbo beskryf is, volgens hierdie leer getrou te bedien...?' (Diensboek van die NHKA, 1997:77; eie beklemtoning). Hieruit blyk dat God se handeling met mense, en die Bybel, telkens aan ' $n$ bepaalde 'leer' (dogma) gelyk-gestel word. Daar word ook van pastors verwag om die Bybel as 'volkome leer van die redding' (wat 'n dogmatiese konstruksie is) te 'glo'. Op hierdie wyse word daar vanuit die staanspoor 'n belydenis oor die Bybel vereis, en word hierdie belydenis oor die Bybel as 'toetssteen' van pastors se geloof in God aangewend. Dit bemoeilik kritiese, wetenskaplike bestudering van die Bybel wat van die kenteoretiese punt uitgaan dat die Bybel nie aan 'God se openbaring' gelykgestel kan word nie, maar eerder dokumente is waarin mense se getuienis oor hulle ontmoeting met God vervat is. Sakkie Spangenberg (2003:13) formuleer hierdie beskouing soos volg: 'Die Bybel is nie die openbaring nie, maar die skrywers daarvan getuig van die openbaring. Die openbaring is agter die teks geleë.' Die 'openbaring agter die teks' kan met Van Aarde se 'Jesus-saak' in verband gebring word' en wel in die sin dat Bybelskrywers in hulle geskrifte oor hulle verhouding (ontmoeting) met God getuig. Spangenberg se uitspraak het egter die hele Bybel in die oog, terwyl Van Aarde hom in sý besinning op die Nuwe Testament toespits.

Indien pastors nie die vermoë ontwikkel om die verskil tussen 'n belydenismatige (dogmatiese) beskouing oor die Bybel, en die wetenskaplike bestudering van Bybelse tekste te begryp en sinvol by hulle bediening te integreer en daarin te verwoord nie, sal hulle in 'n postmoderne tyd voortdurend spanning en verlamming beleef, en veral om die volgende redes:

- Die Bybel is in vele pastors se denke 'die Woord van God' of 'God se openbaring'. Daarom is dit wat in die Bybel geskryf is, 'vas en seker'. Hierdie oortuiging word duidelik wanneer pastors op Sondae die Bybel in die hand neem en vir gemeentes sê: 'Kom ons lees saam uit die Woord van die Here'; wanneer pastors in hulle preke sê: 'Die Here se 
Woord sê ...'; of wanneer pastors die Bybel in die pastoraat aanwend met die frase: 'God sê in die Bybel ...'. Op hierdie wyse word Bybelskrywers se woorde oor God dikwels aan 'God se Woord' gelykgestel (kyk ook die Bybelgebruik in die Diensboek van die NHKA 1997:12-43).

- Baie sake wat voorheen as 'vas en seker' en as 'grondslae van mense se geloof' beskou is, word in die postmoderne tyd gerelativeer. Bybelwetenskaplikes dui met behulp van sosiaal-wetenskaplike, ideologie-kritiese, postkoloniale en vele ander teorieë, modelle en metodes aan dat die Bybel 'n produk is van komplekse sosiale, religieuse, kulturele en politieke prosesse, en dat Bybelboeke en -tekste nie een dimensioneel as 'Woord van God' gelees kan word nie. Die wyse waarop Genesis 2-3, Psalm 51:7 en Romeine 5:12,18-19 funksioneer om 'n grondslag leerstuk oor sonde te lê, dien as voorbeeld hiervan (kyk Spangenberg 2003:100-102). Wanneer die tradisionele beskouing oor 'die sondeval' krities bestudeer word, en daar aangedui word dat die Bybelse tekste wat as grondslag van hierdie 'leerstuk' dien buite konteks vertolk word, ontaard dit vir vele pastors in 'n krisis wat hulle begrip van die kruisiging van Jesus as 'God se straf vir die mens se sonde' en die tradisionele regverdigingsleer betref.

\section{VERWONDING EN VERLAMMING}

Tot dusver dui dié oordenking daarop dat baie pastors hulle nie meer as 'herders en leraars' kan beskou wat 'n 'onkundige kudde skape' moet leer en lei, omdat laasgenoemde dit nie self kan doen nie. Só 'n beskouing oorlaai pastors emosioneel, en wek die indruk dat mense nie as gelyke vennote beskou word wat in staat is om self besluite te kan neem nie. Hierbenewens beskik lidmate van Christelike geloofsgemeenskappe ook oor 'n magdom inligting met betrekking tot die Bybel en religieuse sake, wat van pastors ' $n$ ander benadering as dié van die vroeëre (tradisionele) paradigma vereis. Dít impliseer nie dat pastors nie ' $n$ belangrike rol in mense se lewens te speel het nie. Dit is egter belangrik om te vra watter inhoud pastors aan hulle rol kan gee.

In die moderne era is pastors as 'Woordverkondigers' beskou, wat op grond van hulle opleiding 'n 'greep' op die 'waarheid van die Skrif' het. Daarom het mense gereken dat pastors objektiewe en voldoende antwoorde op mense se probleme kon gee. Modernisme het tot ' $n$ model aanleiding gegee waarvolgens die verwantskap tussen pastors en ander as 'n verwantskap van 'helpers' (pastors) teenoor 'hulpeloses' (ander), beskou is. Aan die hand van hierdie model, wat as die sogenoemde 'mediese/kliniese' model bekend staan (Patton 1993:4-5), is mense 'gediagnoseer', en het pastors die 'regte behandeling' toegepas. Die wyse waarop pastorale sorg deur die mediese model geabsorbeer is, blyk daaruit dat pastorale sorg nie as deel van 'n geloofsgemeenskap se bestaan geag is nie, maar as die spesialiteitsgebied van opgeleide kundiges (Graham 2002:46). Die genesingswonders van Jesus, soos in die evangelies vervat, word in literatuur oor hierdie beskouing aangewend om pastors as genesers voor te stel (kyk Heitink 1984:30-33).

Donald Capps en Gene Fowler (2001) besin in hulle boek, The pastoral care case: Learning about care in congregations, oor die plek van pastors en pastoralesorg in Christelike geloofsgemeenskappe. Volgens dié twee skrywers (Capps \& Fowler 2001:10-11), kan pastorale sorg, soos dit in die 20ste eeu ontwikkel het, na die gebruik van diagnostiese argumentvoering in die mediese wetenskap, soos wat dit deur die medikus, Richard Cabot (1906), ontwikkel is, teruggevoer word. Hierdie metode stel 'n mediese dokter in staat om deur middel van induktiewe en deduktiewe beredenering die verband tussen simptome en siektes uit te wys, op grond waarvan 'n diagnose gemaak kan word. Op grond van die diagnose kan 'n behandelingsplan voorgestel word. Cabot se metode is later op die vakgebied Kliniese Pastorale Opleiding vir teologiestudente gebruik (kyk Nouwen 1977:12-32). Hierdie induktiewe en deduktiewe beredenering staan in die pastoraat as pastorale-sorgberedenering ('pastoral care reasoning') bekend.
Die vakgebied Kliniese Pastorale Opleiding het in 1925 onder leiding van Anton Boisen, die eerste voltydse kapelaan in 'n psigiatriese hospitaal in die Verenigde State van Amerika, tot stand gekom, toe vier teologiestudente onder sy mentorskap met hulle opleiding in Kliniese Pastorale Vorming begin het. Boisen formuleer sy visie om tot die opleiding van pastors by te dra soos volg:

Almost from the beginning of the specialized religious ministration to the mentally ill, upon which I have been engaged during the last twelve years, I have been concerned in a plan for the clinical training of theological students.

(Boisen 1936:250)

Boisen het tot studente-opleiding bygedra deur studente aan te moedig om hulle eie notas van gevallestudies te skryf, en hulle nie tot die dosent se notas te beperk nie (Boisen 1936:260). Boisen, wat uit 'n era kom toe modernisme 'n sterk invloed gehad het, is postmodern in sy benadering in dié sin dat hy nie in die behandeling van psigiatriese pasiënte van Christelike dogmas en leerstellinge uitgaan nie, maar eerder die pasiënte se eie religieuse ervarings as grondslag gebruik (vgl Asquith 1990:24-25)

Die diagnostiese proses was daarop gemik om pastors tot 'n dieper teologiese begrip van mense te bring sodat, pastors daardie mense uiteindelik doeltreffender kan dien. Boisen (1936:252) verwoord hierdie oortuiging soos volg:

We are always seeking to relieve human distress and to train the young minister in the fine art of helping those who are in trouble. We hold that service and understanding go hand in hand. Without true understanding there can be no effective service in that which concerns the spiritual life.

(Boisen 1936:252)

Pastors se diens as gewonde genesers is dus op besondere wyse geleë in 'n poging om mense te verstaan. Sonder begrip, is begeleiding moeilik haalbaar. Pastors wat hulle as 'herders en leraars' beskou, wat met behulp van die Bybel en hulle teologiese tradisies die 'regte antwoorde' op mense se probleme verskaf, sal moeilik na mense luister, en hulle daarom ook moeilik verstaan. Gewonde genesers is mense wat in die eerste plek hulle teenwoordigheid (being) by ander met erns bejeën, en in die twééde plek op dít konsentreer wat hulle moet doen (doing). Om by ander teenwoordig te wees, impliseer dat pastors na ander sal luister voordat hulle iets sê of doen (kyk Hedahl 2001:94-102).

Russell Dicks (kyk Capps \& Fowler 2001:14-18) het vanaf 1933 'n waardevolle bydrae tot die kliniese pastorale vorming van teologiestudente gemaak, en het 'n boek getiteld The art of ministering to the sick (Cabot \& Dicks1936) gepubliseer, waarin 'n model en metode vir bediening aan pasiënte uiteengesit word. Dicks (1939) het Boisen se metode onvoldoende gevind, en het daarom sy eie metode ontwikkel. Dicks se bydrae tot die ontwikkeling van ' $n$ werkbare bedieningsmetode vir pastors is daarin geleë dat hy alles wat hy van 'n gesprek met 'n pasiënt kon onthou, neergeskryf het, en hierdie notas dan met sy studente gedeel het om uit te vind wat hulle in soortgelyke omstandighede sou doen.

Vir Cabot en Dicks (1936:244) was die doel van besoekverslae om pastors tot insig te bring in die mense met wie hulle te doen het, en nie net om 'n probleem ('siekte') te diagnoseer wat behandel moet word nie. Dicks (1949) het later met sy boek, Pastoral work and counselling, die voorloper geword van ' $n$ model wat in die tweede helfte van die 20ste eeu 'n groot invloed op pastorale sorg en terapie gehad het (Capps \& Fowler 2001:20). Hiermee het Dicks die metode wat in hospitaalverband gebruik is, vir pastors se gemeentelike bediening aangepas, en word pastors se bediening as ' $n$ spirituele saak beskou wat deur die teologie gerig word. Dicks (1949:vii) formuleer dit soos volg: 'Pastoral care is as old as religion. It means ministry to individuals. In its traditional sense it means shepherding of souls, or cure of souls.' Hierdie oortuiging dat pastoraat die 'shepherding of souls, 
or cure of souls' is, dui daarop dat psigologiese insigte op sigself nie die doel van pastors se betrokkenheid by mense is nie, maar dat pastors sodanige insigte sal aanwend om mense teologies (geestelik/spiritueel) te begelei.

Seward Hiltner het in sy boek, Pastoral counseling (1949), Dicks se pastoraatmodel verder ontwikkel, maar die fokus vanaf die kliniese(hospitaal-)konteksna diegemeentelikekonteks verskuif. In 'n latere werk, Preface to pastoral theology (1958), ontwikkel Hiltner pastorale teologie as formele teologiese dissipline, en voer hy aan dat pastorale teologie daarop gemik is om alle bedieninge van pastors uit die perspektief van herderskap ('shepherding') te beredeneer (Hiltner, 1958:24). Hiermee neem hy afskeid van die sogenoemde 'pastorale-sorg-terminologie', en ontwikkel hy 'n nuwe model vir die bediening, waarvolgens pastorale sorg aan die hand van drie perspektiewe beskryf word, naamlik: die wyse waarop pastors mense as herders begelei, die oordrag van die evangelie, en die organisering van die geloofsgemeenskap (kyk Hiltner 1958:55-85). Hiltner (1958:89-172) onderverdeel herderskap in drie subdomeine, naamlik genesing ('healing'), ondersteuning ('sustaining') en begeleiding ('guiding'). Genesing beteken om heel ('whole') te word (kyk Hiltner 1958:89-115) en behels die verbinding van wonde in die gees van die gelykenis oor die barmhartige Samaritaan, maar:

[i]t does not necessarily imply that the result of the healing will be the same in its particulars as the condition that [was] previously obtained, except for the one characteristic of wholeness. ... Thus healing is to be understood as the process of restoring functional wholeness.

(Hiltner 1958:89; eie beklemtoning)

Ondersteuning het ten doel om persone by te staan, al is genesing op ' $n$ bepaalde tyd in hulle lewe nie moontlik nie, of al vind dit glad nie plaas nie (kyk Hiltner 1958:116-144). Hiltner (1958:116) verwoord dit soos volg: 'Sustaining is the ministry of support and encouragement through standing by when what had been a whole was broken or impaired and is incapable of total situational restoration, or at least not now.' Begeleiding het ten doel om mense op morele en religieuse vlak op hulle lewensreis te vergesel (kyk Hiltner 1958:145-172). Hiltner (1958:145) wys daarop dat ' $n$ begeleier nie die persoon wat begeleiding nodig het volledig ken nie. Mense se kennis oor hulleself en hulle omstandighede is altyd meer as dié van die begeleier. Daarom voer Hiltner (1958:145) die volgende aan: 'A spiritual guide is more than a reflective mirror. But he is not in any sense a director in a way that implies coercion.'

Wat vir pastors van belang is, is die verband wat Hiltner tussen herderskap en die verbinding van wonde uitwys. Die belang van die genesingsaspek van pastors se bediening word soos volg deur Hiltner verwoord (1958:115): '[F]or a complete study of pastoral operations from the healing aspect of the shepherding perspective, all these [sermons, religious education, group work] and others must be examined'. In die teoretiese raamwerk van die studie waaruit hierdie artikel spruit, kan pastors op 'n helende wyse by ander betrokke wees, terwyl hulle self in die proses innerlike genesing en transformasie ervaar.

Bogenoemde oordenking lei tot die insig dat pastors subjektief by alle aktiwiteite in hulle bediening betrokke is, en dat dit hulle bediening beïnvloed. Dit is belangrik dat pastors hierdie saak erken en dit in hulle teologiese besinning en praktiese bediening in ag neem indien hulle op ' $n$ skeppende en helende wyse met die verwonding en verlamming in hulle eie én ander se lewens wil omgaan. Die belang van hierdie saak word vervolgens aan die hand van ' $n$ onlangse ontwikkeling in die postmoderne epistemologie ${ }^{2}$, naamlik 'outobiografiese Bybelkritiek', beskryf.

2.Epistemologie kan as die filosofiese besinning oor wetenskaplike kennis beskryf word. Dit is die doelbewuste ondersoek na die oorsprong, aard, taal, struktuur, potensiaal vir sinvolle beskrywing, en die beperkings van kennis, asook die wyse waarop kennis bekom word (Deist 1984:84).

\section{OUTOBIOGRAFIESE PASTORAAT}

In hierdie paragraaf word daar voortgebou op die werk deur Flip Schutte (2005:401-416) oor outobiografiese Bybelkritiek, en oor die betekenis daarvan vir die pastoraat nagedink.

Outobiografiese Bybelkritiek gaan van die teorie uit dat onbetrokke, afsydige leesstrategieë en vertolking van tekste nie moontlik is nie. Hierdie teorie stel dit verder dat enige skrywer van enige teks subjektief by die skryfproses betrokke is. Dít geld ook die skryf van akademiese werk. Die afgelope 20 jaar is daar in filosofiese besinning oor epistemologie sterk op die problematiek van lesers, en lesers se betrokkenheid by teksvertolking gekonsentreer (Fowler 1995:232). Hierdie oordenking konsentreer op die insig dat lesers vir hulle eie teksvertolking verantwoordelikheid moet aanvaar, sonder om voor te gee dat hulle vertolking die enigste en korrekte betekenis van tekste weergee. Laasgenoemde saak is een van die belangrike katalisators van die huidige oplewing in outobiografiese kritiek.

Mense lees tekste vanuit hulle eie konteks, wat hulle ekonomiese, spirituele, kulturele, politieke en emosionele ervarings insluit. Hierdie besef maak ' $n$ belangrike deel van die teorie in hierdie studie uit, naamlik dat pastors nie op 'n kil, kliniese wyse met mense, met hulleself, met die Bybel en teologiese tradisie, en met hulle bedieningspraktyk omgaan nie. Cas Vos (1996:197-255) het ' $n$ soortgelyke saak met betrekking tot die prediking onder die term 'hoordershermeneutiek' beredeneer. In sy oordenking dui Vos aan op watter wyses erediensgangers subjektief by die erediens en by die aanhoor en vertolking van pastors se prediking betrokke is (kyk Vos 1996:226-227). Op grond van 'n bepaalde ervaring van die werklikheid, vertolk en kontsrueer mense hulle werklikheid, en poog hulle om in daardie werklikheid sin te skep. James F. Kay (2003:16-35) beskou prediking as 'theologically authorized rhetoric', en voer aan dat prediking getrou is aan God se Woord indien hoorders dit in hulle eie lewensverband kan toepas. Kay formuleer predikers se verantwoordelikheid om hulle hoorders by die voorbereiding en aanbieding van hulle prediking in ag te neem, soos volg:

..., God accompanies the creature, honoring each one's dignity, integrity, and particularity ... This Good News of God's own giving to each creature what is contextually fitting and appropriate to it, with full regard for its particularity, authorizes the church's own concursus in the ministry of this Word. Our own words of witness are to be fitting and appropriate to our listeners.

(Kay 2003:34)

Binne die bestek van twee artikels besin Hennie Pieterse (2005a:77-95; 2005b:110-128) oor die vraag hoe God in pastors se prediking aan die woord kan kom. In die eerste artikel formuleer Pieterse sy probleemstelling, en gee hy 'n kort oorsig van die wending wat in die homiletiek plaasgevind het, naamlik van 'n uitsluitlike fokus op God wat in die prediking aan die woord kom, na die rol van die hoorder in die homiletiese proses. In die tweede artikel gebruik Pieterse 'n gepubliseerde preek wat aartsbiskop Desmond Tutu in 1990 Rustenburg by 'n byeenkoms van verskillende kerke gelewer het, om sy pleidooi dat God in menslike situasies aan die woord moet kom, te illustreer (kyk Pieterse 2005b:110-128). Pieterse (2005a:88-89) wys op die antroposentriese wending wat ná die Tweede Wêreldoorlog na vore gekom het, waarin die klem daarop begin val het dat pastors hulle prediking aan die hand van sowel hulle eie situasies as dié van die mense vir wie hulle preek, moet oordra. Pieterse (2005a:89) formuleer hierdie wending na die hoorder in die homiletiek soos volg: 'Die homiletiese situasie van die hoorder moet eksistensieel geken word en dan in die lig van die evangelie verhelder word sodat daar egte verandering kan kom.' Met die ontwikkeling van die sogenoemde 'nuwe homiletiek' in die Verenigde State van Amerika, het daar egter ' $n$ wanbalans in hierdie klem op die hoorder ontstaan, wat daarop uitloop dat God se liefde en genade in Jesus Christus nie oorgedra word nie, maar dat prediking vir die hoorders 'n 'ervaringsgeleentheid' word (kyk Immink 2004:101). 
Outobiografiese kritiek behels deursigtigheid by pastors ten opsigte van hulle subjektiewe betrokkenheid by dit waarmee hulle besig is. Dít veroorsaak die siening dat pastors hulle lees van tekste, hulle wisselwerking met mense, en hulle bedieningspraktyk as 'n aaneenlopende proses met ruimte vir groei en transformasie beskou. Die groei en transformasie waarvan hier gepraat word, beteken dat pastors hulle vertolking van die Bybel en mense se lewensomstandighede nie as die enigste vertolking beskou nie, maar dat hulle verstaan dat hulle dít wat hulle lees en dít wat hulle by mense hoor, vanuit hulle eie konteks vertolk. In hierdie verband wys D.A. Hagner (1995:58) daarop dat daar nie so iets soos 'objektiewe' vertolking bestaan nie, maar dat alle mense tekste met hulle eie voorveronderstellings benader. In afdeling 3 van hierdie artikel is daarop gewys dat pastors soms kognitiewe dissonansie beleef, onder andere op grond van 'n Skrifbeskouing wat in 'n postmoderne era oënskynlik op 'n anomalie dui. Die teorie oor outobiografiese Bybelkritiek is vir hierdie studie van belang, omdat dit pastors kan help om hulle eie konteks op 'n sinvolle wyse by hulle lees van die Bybel te integreer. Omdat nóg die lees van tekste nóg postmoderne vertolking 'n onbetrokke aktiwiteit is (kyk Rohrbaugh 1995:248), hou outobiografiese kritiek die voordeel in dat pastors van die ontmoeting tussen hulle persoonlike en beroepslewens bewus raak. Dít sal pastors daarvan weerhou om hulle eie vertolking van die Bybel as die 'enigste waarheid' aan te bied. Om die eie Skrifbeskouing as 'die korrekte beskouing' aan te bied, en op dié wyse ander se oortuigings as minder belangrik te ag, kan 'n donker kant van pastors se psige openbaar. Outobiografiese pastoraat bied ' $n$ geleentheid om deur die bewustelike verwoording van die eie lewensverhaal, tersaaklike episodes en temas wat met die skadukant in pastors se lewens in verband gebring kan word, te formuleer. Sodoende kan pastors insien dat daar verskillende geldige beskouinge kan wees, omdat die vertolking van die Bybel die netwerk verwantskappe tussen die persoonlike en sosiale omgewing van lesers (én van pastors), sowel as die effek daarvan op die lees van die Bybel, openbaar (kyk Anderson \& Staley 1995:11). Omdat geen navorsing in 'n vakuum gebeur nie, bied outobiografiese kritiek kritici en pastors die geleentheid om belangrike fasette van hulle menswees in hulle optrede, prediking en akademiese werk oor te dra. Selfs al word 'persoonlike blootlegging' nie pertinent uitgespel nie, kan dit op die subteksvlak waargeneem word. Getuigskrifte kan hier as voorbeeld dien: Dit wat nié oor 'n persoon gesê word nie, spreek gewoonlik harder as dit wat wél gesê word. Hierdie opmerking is van belang omdat pastors, vanweë 'n bepaalde selfbeskouing as mense wat 'namens God' belangrike dinge aan mense moet oordra (kyk Vos 1996:197-255), hulle eie worsteling met die lewe, met hulle persoonlike geloof, en met die Bybel kan ontken. Outentieke self-onthulling kan egter 'n positiewe uitwerking op pastors se wisselwerking met mense hê. Natuurlik sal nie alle pastors ewe gemaklik met self-onthulling wees nie. Die moontlike redes hiervoor is uiteenlopend:

- Pastors funksioneer vanuit 'n moderne wetenskapsbeskouing, met die oortuiging dat hulle die 'suiwer evangelie/ woord van God' verkondig, en dat hulle persoonlike lewens nie in hierdie proses van belang is nie, omdat dit in sogenaamde subjektivisme en relativisme kan 'ontaard'

- Verskillende pastors het verskillende persoonlikheidstipes

- Pastors se persoonlike lewensverhale stimuleer óf onderdruk outentieke self-onthulling.

Outobiografiese kritiek maak deel uit van 'n breër postmoderne ontwikkeling in die wetenskapsfilosofie, en erken dat daar nie iets soos 'suiwer objektiewe' wetenskap en kritiek (of pastoraat) bestaan nie. Postmoderniteit kan oor die algemeen as 'n reaksie op die oorheersing van moderniteit beskou word, en verwys na 'n denkpatroon wat klassieke beskouings oor waarheid redelikheid en objektiwiteit met agterdog bejeën (kyk Adam 1995; Rossouw 1993:894-907). A.K.M. Adam (1995:4) wys daarop dat postmoderniteit deur minstens drie sake gekenmerk word, wat soos volg saamgevat kan word:
- Postmoderniteit is teengrondliggend ('antifoundationalist') omdat dit nóg enige absolute waarhede, nóg enige enkele veronderstelling as moontlike grondslag vir die waarheid aanvaar (Adam 1995:5).

- Postmoderniteit is in die tweede plek teengeheelvormend ('antitotalising'). Dít beteken dat geen teorie daarop kan aanspraak maak dat dit die geheelbeeld of volledige verklaring van die werklikheid of verskynsels in die werklikheid verskaf nie. Van Aarde verwoord hierdie saak soos volg:

Information contradicting a theory or providing another possible angle can always be found. If a theory claims to be 'total', it in effect means that the other possibilities that do not exist have simply been disregarded or the criteria were designed to eliminate them.

(Van Aarde 2002:431)

Geheelvormende denke kom byvoorbeeld voor in die wyse waarop sekere maatstawwe ingesluit en ander opsygeskuif of geheel en al geïgnoreer word. Adam (1995:8) vra egter die belangrike vraag: Wie besluit wat ingesluit en wat uitgesluit word? Op grond waarvan word hierdie besluit(e) geneem? Watter oorwegings lei daartoe dat bepaalde sake as aanvaarbaar en ander as onaanvaarbaar geag word? Die huidige homoseksualiteitsdebat in Suid-Afrikaanse geloofsgemeenskappe dien as illustrasie. Teenstanders van homoseksualiteit as ' $n$ aanvaarbare vorm van menswees, en daarom ook teenstanders van homoseksuele verhoudings, het ' $n$ geheelvormende beskouing oor presies hoe daar oor seksualiteit gedink mag word, en hoe nie, naamlik dat slegs heteroseksualiteit 'normaal' is, en dat dit boonop 'in God se Woord' so 'beveel' word.

- In die derde plek kan postmoderniteit as ontsluierend ('demystifying') beskryf word (Adam 1995:5). Versluiering beteken dat sekere sake eenvoudig as 'natuurlik' en ander as 'onnatuurlik' geag word, en dat hierdie onderskeid onder andere religieus regverdig word. 'n Eietydse illustrasie hiervan is die wyse waarop politici die Christelike godsdiens ingespan het om die Verenigde State van Amerika se jongste oorlog teen Irak te regverdig. In die kerk gebruik vele pastors en lidmate steeds die Bybel (as 'God se Woord') om kerklike skeiding tussen rasse en kulture te staaf. Postmoderniteit ontmasker die grondslag van vele argumente as verskuilde ideologiese projeksies (Van Aarde 2002:431), byvoorbeeld rassistiese, politieke en ekonomiese beweegredes. Ontsluiering loop uit op voortdurende selfgesprek, kritiese selfbesinning en derhalwe bevraagtekening van eie standpunte. Dít beteken dat die beredenering in hierdie artikel ook krities beskou moet word, en dat daar gevra moet word watter ideologiese motiewe onderliggend is aan die teorie dat pastors as gewonde genesers behoort te leef en funksioneer. Die teorie of die metafoor van gewonde geneser kan nie versluier word deur te beweer dat dit 'die Bybelse model' is waarvolgens daar oor pastors gedink 'moet' word nie. Die werklikheid is altyd groter en meer as net ' $n$ enkele perspektief. Die perspektief in hierdie artikel is maar een van baie. Hierdie gedagte kom ook sterk na vore in die gebruik van verskillende metafore met betrekking tot die pastoraat in Robert Dykstra (2005a) se bundel opstelle. Dykstra verwoord die relatiwiteit van die verskillende metafore in die pastoraat soos volg:

In gathering these images into one volume, I hope in turn to help ministers and seminary students not only to readily discern those dominant or 'default' metaphors that typically orient their own pastoral styles, but also to discover an array of alternate metaphors for imagining their way into those inevitable circumstances in ministry in which a fresh vision and new approach are warranted.

(Dykstra 2005b:8)

Hierdie benadering vereis oop, vindingryke denke van pastors, en 'n deurlopende, selfkritiese besinning oor die onderliggende motiewe waarom pastors (dikwels onbewus) sekere metafore en bedieningstyle kies. Dykstra se formulering vestig ook die aandag op die gegewe dat konteks 'n belangrike rol in pastors se 
keuses speel, hetsy ' $n$ keuse vir 'n bepaalde standaard metafoor, of 'n keuse om doelbewus in bepaalde omstandighede op 'n ander standaardwyse as die 'normale een' te funksioneer (kyk Dykstra 2005c:123-136)

Voormelde beskrywings se waarde vir hierdie studie en vir die pastoraat is dat daar stelselmatig van geykte, vaste, afgeslote en outokratiese beskouings oor pastors, pastoraat en kerklike bediening afstand gedoen word. Die moderniteit het tot gevolg gehad dat enkele beskouings oor pastoraat en pastors as 'die korrekte, Bybelse' beskouings voorgehou is, byvoorbeeld die sogenoemde herder-metafoor, en pastors as leraars. Ten spyte van die moderne argument dat die Bybel histories krities gelees word, is die feit dat Bybelse geskrifte 'histories geplaaste' dokumente is nie by die formulering van amptelike dokumente, soos bevestigingsformuliere van kerkampte, in ag geneem nie. Aan die hand van die voormelde drie kenmerke van die postmodernisme, is die bevestigingsformuliere van die NHKA (kyk Diensboek van die NHKA 1997:75-85) oënskynlik 'n argetipe van die moderne paradigma, en word dit al hoe meer deur die postmoderne paradigma uitgedaag. Die wyse waarop die praktiese inrigting van antieke geloofsgemeenskappe as voorskrif vir die inrigting van postmoderne geloofsgemeenskappe en bediening deur pastors geag word, word toenemend in twyfel getrek. Postmoderne denke bevraagteken sodanige denkwyses deur onder andere te ondersoek in wie se belang die besondere formulerings in dié formuliere is. Een van die afleidings wat gemaak kan word, is dat die ampte van leraar, ouderling en diaken op 'versluierende wyse' as 'God se bedoeling met die kerk' beskryf word, met die doel om gesagstrukture waardeur beheer oor mense uitgeoefen kan word, te vestig. Hierdie versluierende aspekte is ook in die gebede in die formuliere te vind.

Wanneer daar in hierdie studie van die ontwikkeling van outobiografiese Bybelkritiek vir die pastoraat gepraat word, is dit derhalwe om doelbewus ook my eie persoon en persoonlikheid, sowel as die wyse waarop hierdie sake my studie oor pastors as emosioneel intelligente, gewonde genesers beïnvloed het, aan die orde te stel. Outobiografiese pastoraat as 'n uitvloeisel van postmoderne kritiek hóéf nie'n negatiewe uitwerking op pastors se funksionering te hê nie, maar kan vir hulle die aanvang van ' $n$ skeppende proses beteken waarin hulle oor hulle bediening as 'n nimmereindigende ontdekkingstog deur die lewe kan besin, en nie as afgeslote oomblikke van geheelvormende, outokratiese uitsprake nie. Pastors se lewe en teologiese oordenking vorm 'n ineengevlegte geheel. Fowler formuleer soos volg:

Autobiographical criticism [pastoraat] seeks not the implied reader [pastor] as much as the impaled reader [pastor], a real, flesh-andblood person pierced by the tenterhooks of history, culture, and personal experience.

(Fowler 1995:234)

Hierdie beskouing oor subjektiewe betrokkenheid laat ontstaan die moontlikheid van voortdurende gesprek, omdat pastors besef dat hulle met hulle hele bestaan by elke dimensie en faset van hulle bedieningspraktyk betrokke is. Dit laat pastors ook besef dat hulle bediening ' $n$ skeppende proses is, waarin die betrokkenheid van God by hulle eie en ander mense se lewens telkens op nuwe wyses ontvou. Die Bybel en teologiese tradisie word steeds as historiese tekste gerespekteer, maar word nie as gestolde waarhede oor God, mens, omgewing en godsdiens beskou nie. Hierdie tekste word eerder as mense se verwoording van hulle ervaring van God en menswees beskou, en dien as toegangspoort tot gesprek en oordenking vir pastors oor hoe om sin in hulle bestaan te skep. Outobiografiese pastoraat laat derhalwe ruimte vir kontekstualisering, kultuur en ervaring (kyk Moore 1995:26). Volgens Anderson en Staley (1995:12) kan dit egter ' $n$ bedreigende en senutergende ervaring vir teoloë (en pastors) wees om te ontdek in watter mate hulle persoonlike ervarings en sosiale posisie hulle professionele omgang met die Bybel (en pastors se bedieningspraktyk) beïnvloed.
My eie standpunt met betrekking tot die Bybel is nie dat dit God se Woord is nie, maar mense se verwoording van hulle ervarings van God in hulle eie lewens, in die omstandighede waarin hulle hulle bevind het. Die tekste in die Bybel is nie allereers vir mense in die 21ste eeu geskryf nie, maar vir premoderne mense in 'n Mediterreense omgewing. Dít was 'n wêreld met sosiale, kulturele, politieke en religieuse gebruike wat radikaal van die postmoderne wêreld waarin ek leef, verskil. Dieselfde geld kerkhervormers soos Martin Luther en Johannes Calvyn, en die mense wat by die skryf van Reformatoriese belydenisskrifte betrokke was. Hoewel ek steeds die belydenisskrifte as historiese verwoordings van mense se geloof respekteer, lees en vertolk ek nie die Bybel soos hulle nie, en ag ek dit ook nie nodig om my ervaring van en geloof in God op dieselfde wyse as hulle te formuleer nie. Die verandering wat oor die afgelope twee dekades in my eie lewe en denke na vore getree het, maak deel uit van allesomvattende veranderings in my leefwêreld. Daarom is persoonlike spiritualiteit belangriker as reëls en voorskrifte oor hoe om Christelik te leef, en stellings oor hoe om 'eendag hemel toe te gaan'. Ek lees en vertolk die Bybel ook op hierdie vlak as dokumente waarin ek van ander se geloofsworsteling bewus raak, sodat hierdie getuienisse in my eie lewensverhaal kan weerklank vind en my in die voortdurende soeke na 'n genadige God kan help. Dit is op hierdie punt waar my verhaal ook met dié van Henri Nouwen ineenloop. Nouwen se werke getuig van 'n beskouing oor spiritualiteit wat met my ervarings, geloof en denke ooreenstem. Dit is 'n spiritualiteit wat nie noodwendig in geïnstitusionaliseerde kerklike en kerkordelike konstrukte en strukture tot uiting kom nie, maar in ' $n$ intieme verhouding met God waarin die Bybel en ander tekste' $n$ sinvolle plek inneem. Dit is ook ' $n$ spiritualiteit wat in 'n ervaring van afhanklikheid van God tot uiting kom, en nie net in 'n blote intellektuele 'kennis' van God wat in dogmas en belydenisskrifte geopenbaar word nie. Hierdie ontwikkeling in my spiritualiteit maak deel uit van 'n groter ontwikkeling in die gemeenskap, naamlik dat mense steeds in God belang stel, maar nie meer in gevestigde kerke nie (kyk Woods 1996:88).

Die roete waarlangs my spiritualiteit begin vorm aanneem het, maak voorts deel uit van 'n proses oor 'n hele aantal jaar waarin ek al hoe meer van die uitwerking van my emosionele belewenisse op my ervaring van God en my godsdienstigheid bewus geword het. Hierdie ervarings het daartoe gelei dat ek die wisselwerking tussen emosies en religieuse belewenisse en ontwikkeling begin ondersoek het. Leeswerk oor die verskynsel van depressie, my ervarings in episodes van major depressie, en die belewenis van Godsverduistering gedurende sulke episodes, het my belansgstelling in die verband tussen emosionaliteit, religie en spiritualiteit verder aangewakker. Emosionaliteit en emosionele intelligensie maak ongetwyfeld ' $n$ integrale deel van die ontwikkeling van spiritualiteit uit. In sy werk, Alone in the world? Human uniqueness in science and theology, beskryf Wentzel van Huyssteen (2006:257-258) die wyse waarop die menslike brein aan menslike ervarings van die werklikheid betekenis gee. Van Huyssteen bou voort op die navorsing van Eugene d'Aquili en Andrew Newberg (1999) om 'n 'neuroteologie' te ontwikkel, waarmee hulle neurowetenskaplike verklarings vir religieuse ervarings probeer bied. Die term 'neuroteologie' word op interdissiplinêre vlak gebruik om gesprek tussen die neurowetenskap en teologie te stimuleer in die gesamentlike soeke na breinstrukture wat met religieuse en mistieke ervarings korreleer (Van Huyssteen 2006:257). Die waarde van D'Aquili en Newberg se navorsing (kyk 1999; en 2001 saam met Vince Rause) is onder andere daarin geleë dat hulle 'n model vir religieuse ervarings ontwerp het waarin prosesse in die brein in sy geheel in ag geneem en ondersoek word. Van Huyssteen (2006:257-258) bespreek verskillende sogenoemde 'operateurs' soos ook deur D'Aquili en Newberg (1999:150-173) onderskei, waarmee die menslike brein in staat is om aan verskillende dimensies van religieuse ervaring uiting te gee.

Die een 'operateur' wat vir hierdie studie van belang is, is die emosionelewaarde-operateur ('emotional value operator') wat die 
ervaring en verdieping van persoonlike religieuse gevoelens / emosies stimuleer (kyk D'Aquili \& Newberg 1999:166-173). David Lewis-Williams (2002:290) se navorsing dui daarop dat mense, veral in die dele van die brein wat emosionele belewenisse beheer, goddelike entiteite as werklikhede ervaar. Wat vir hierdie studie van belang is, is die aandag wat dit op emosies en emosionele belewenisse in mense se verhouding met God vestig, met ander woorde die verband wat volgens die navorsing tussen spiritualiteit en emosionaliteit bestaan. Dat emosionaliteit en die ontwikkeling van emosionele intelligensie ' $n$ komplekse saak is, sal uit ' $n$ volgende artikel oor emosionele intelligensie blyk. In die raamwerk van voormelde beredenering kan daar egter aangevoer word dat ontwikkeling van emosionele intelligensie by pastors tot die gesonde en outentieke ontwikkeling van hulle verhouding met God kan lei. Emosionele intelligensie beteken in hierdie verband pastors se insig dat mense se Godskonsep(te) nie een dimensionele, dogmatiese konstrukte is of behoort te wees nie, maar eerder dinamiese prosesse wat met breinontwikkeling en -stimulering saamhang. Trouens, dit beteken dat pastors insig ontwikkel in die wyse waarop mense se totale kontekste (wat hulle emosionele ontwikkeling insluit) aan hulle Godskonsepte vorm gee, en dat mense in verskillende lewensfases verskillende opvattings oor God kan hê. Hierdie besef sal pastors help om minder dogmaties en outoritêr oor hulle eie Godskonsepte te wees. Dit sal pastors ook in staat stel om moontlike fases van twyfel aan God (in besonder aan Godskonsepte wat deur kerklike belydenisskrifte gevestig is) nie summier as 'dwaalleer' of 'kettery' af te maak nie, maar dit eerder as tekens van lewe en persoonlike transformasie te waardeer.

Die besef van die kernrol wat breinprosesse in my eie emosionele belewenisse en spiritualiteit speel, maak deel uit van my lewensverhaal en -reis. Dié besef is belangrik vir my besinning oor outobiografiese pastoraat vanweë my persoonlike oortuiging dat eerlikheid oor my subjektiewe betrokkenheid by die navorsingstema en -materiaal sinvolle ontwikkeling van die navorsingsproses in die hand werk. Hoewel dit 'n riskante onderneming is om iets van myself in 'n akademiese werk te openbaar, is dit belangrik om te meld dat hierdie studie vanuit my persoonlike lewensreis gebore is. Ek kan nie anders nie as om met Julia O'Brien (1995:119) saam te stem wanneer sy sê: 'I am aware of the problems of self-disclosure, the possibility that biblical studies could collapse into 'what the text means to me,' into an orgy of the ego. And yet, I am uncomfortable with the alternative.

Selfopenbaring, wat op ' $\mathrm{n}$ besondere wyse met emosionele intelligensie en die konsep gewonde geneser saamhang, hoef nie op subjektivisme uit te loop nie, maar kán sinvol deel uitmaak van pastors se teologiese besinning en bediening.

\section{NOTA}

Hierdie artikel is ' $n$ verwerking van ' $n$ deel van hoofstuk 1 uit S. Philip Nolte se PhD-proefskrif getiteld, 'Pastors as gewonde genesers - Emosionele intelligensie en pastoraat', onder leiding van Prof. Yolanda Dreyer, Departement Praktiese Teologie, Fakulteit Teologie, Universiteit van Pretoria.

\section{LITERATUURVERWYSINGS}

Adam, A.K.M., 1995, What is postmodern biblical criticism? Fortress Press, Minneapolis.

Altieri, C., 1990, Canons and consequences: Reflections on the ethical force of imaginative ideals, Northwestern University Press, Evanston.

Anderson, J.C. \& Staley, J.L., 1995, 'Taking it personally: Introduction', Semeia 72, 7-18.

AAsquith, G.H. (Jnr), 1990, 'An experiential theology', in L. Aden \& J.H. Ellens (reds.), Turning points in pastoral care: The legacy of Anton Boisen and Seward Hiltner, pp. 19-31, Baker Book House, Grand Rapids.

Baarda, T.J., Davidse, J., Firet, J., Den Heyer, C. J., De Moor, J.C., Van Peursen, C.A. et al., 1981, God met ons: ... over de aard van het Schriftgezag ...., Tijl-Libertas, Utrecht.
Boisen, A.T., 1936, The exploration of the inner world, Harper and Brothers, New York.

Burton, L.A., 1988, Pastoral paradigms: Christian ministry in a pluralistic culture, Alban Institute, Washington, DC.

Buswell, G. vertl, 1968, Introduction to the New Testament: An approach to its problems, deur W. Marxsen (red.), Fortress Press, Philadelphia.

Cabot, R.C., 1906, Case teaching in medicine: A series of graduated exercises in the differential diagnosis, prognosis and treatment of actual cases of disease, DC Heath and Co, Boston.

Cabot, R.C. \& Dicks, R.L., 1936, The art of ministering to the sick, Macmillan, New York.

Capps, D. \& Fowler, G., 2001, The pastoral care case: Learning about care in congregations, Chalice Press, St. Louis.

Chapman, S.B., 2000, The law and the prophets: A study in Old Testament canon formation (Forschung zum Alten Testament), Mohr Siebeck, Tübingen.

D'Aquili, E. \& Newberg, A., 1999, The mystical mind: Probing the biology of religious experience, Fortress Press, Minneapolis.

D'Aquili, E., Newberg, A. \& Rause, V., 2001, Why God won't go away: Brain science and the biology of belief, Ballantine Books, New York.

Dicks, R.L., 1939, And ye visited me: Source book for ministers in work with the sick, Harper and Brothers, New York.

Dicks, R.L., [1944] 1949, Pastoral work and personal counselling, Macmillan, New York.

Deist, F., [1984] 1990, A concise dictionary of theological and related terms. Second revised and enlarged edition, JL van Schaik, Pretoria.

Diensboek van die Nederduitsch Hervormde Kerk van Afrika, [1987] 1997, Kital, Pretoria.

Dykstra, R.C., 2005a, Images of pastoral care: Classic readings, Chalice Press, St. Louis.

Dykstra, R.C., 2005b, 'Introduction', in R.C. Dykstra (red.), Images of pastoral care: Classic readings, pp. 1-14, Chalice Press, St. Louis.

Dykstra, R.C., 2005c, 'The intimate stranger', in R.C. Dykstra (red.), Images of pastoral care: Classic readings, pp. 123-136, Chalice Press, St. Louis.

Farley, E., 1996, Deep symbols: Their postmodern effacement and reclamation, Trinity Press International, Valley Forge.

Fowler, R.M., 1995, 'Taking it personally: A personal response', Semeia 72, 231-238.

Graham, E.L., [1996] 2002, Transforming practice: Pastoral theology in an age of uncertainty, Wipf and Stock Publishers, Eugene.

Hagner, D.A., 1995, 'Writing a commentary on Matthew: Selfconscious ruminations of an evangelical', Semeia 72, 51-72.

Hedahl, S.K., 2001, Listening ministry: Rethinking pastoral leadership, Fortress Press, Minneapolis.

Heitink, G., [1977] 1984, Pastoraat als hulpverlening: Inleiding in de pastorale theologie en psychologie, JH Kok, Kampen.

Hiltner, S., 1949, Pastoral counseling, Abingdon Press, Nashville.

Hiltner, S., [1954] 1958, Preface to pastoral theology, Abingdon Press, New York.

Immink, F.G., 2004, 'Homiletics: The current debate', International Journal of Practical Theology 8, 89-121.

Kay, J.F., 2003, 'Reorientation: Homiletics as theologically authorized rhetoric', The Princeton Seminary Bulletin 24(1), $16-35$.

Kerkorde van die Nederduitsch Hervormde Kerk van Afrika s.j. Gewysig volgens die besluite van die 67ste Algemene Kerkvergadering, Pretoria.

Kuhn, T.S., [1962] 1970, The structure of scientific revolutions, University of Chicago, Chicago.

Lewis-Williams, D., 2002, The mind in the cave: Consciousness and the origin of art, Thames and Hudson, New York.

Malherbe, P.B. \& Louw, D.J., 2002, 'Die dinamika tussen teologiese paradigmas en die verskynsel van uitbranding in die bediening', Nederduits Gereformeerde Teologiese Tydskrif $43(3 \& 4), 513-522$.

Moore, S.D., 1995, 'True confessions and weird obsessions: Autobiographical interventions in literary and biblical studies', Semeia 72, 19-50. 
Mouton, J., 1987, 'Die positivisme', in J.J. Snyman \& P.G.W. du Plessis (reds.), Wetenskapsbeelde in die geesteswetenskappe. (RGN-Studies in Navorsingsmetodologie 3), pp. 1-29, Raad vir Geestesnavorsing, Pretoria.

Nolte, S.P. \& Dreyer, Y., 2008, 'Pastors as gewonde genesers: Die emosionele uitwerking van kognitiewe dissonansie', Hervormde Teologiese Studies 64(2), 1005-1020.

Nouwen, H.J.M., 1977, 'Boisen and the case study method', The Chicago Theological Seminary Register 67, 12-32.

O'Brien, J.M., 1995, 'On saying 'no' to a prophet', Semeia 72, 111124.

Patton, J., 1993, Pastoral care in context: An introduction to pastoral care, Westminster/John Knox Press, Louisville.

Pieterse, H.J.C., 2005a, 'Hoe kom God aan die woord in die prediking? Die probleemstelling', Praktiese Teologie van SuidAfrika 20(1), 77-95.

Pieterse H.J.C., 2005b, 'Hoe kom God aan die woord in die prediking? 'n Vaste vertroue op God se beloftes is noodsaaklik', Praktiese Teologie van Suid-Afrika 20(2), 110128.

Rohrbauch, R.L., 1995, 'A social scientific response', Semeia 72, 247-258.

Rossouw, G.J., 1993, 'Theology in a postmodern culture: Ten challenges', HTS Teologiese Studies/Theological Studies 49(4), 894-907.

Schutte, P.J.W., 2005, 'When they, we, and the passive become I - Introducing autobiographical biblical criticism', HTS Teologiese Studies/Theological Studies 61(1\&2), 401-416.
Spangenberg, I.J.J., 2003, Teologie op die markplein: 'n Postapartheid teoloog dink na oor sy geloof en leefwêreld, CB Powell Bybelsentrum, Pretoria.

Ter Borg, M.B., 1998, 'Canon and social control', in A. van der Kooij \& K. van der Toorn (reds.), Canonization and decanonization (Studies in the History of Religions 82), pp. 411-423, Brill, Leiden.

Van Aarde, A.G., 1999, 'Wat is waarheid? 'n Teologiese antwoord van;n Bybelwetenskaplike,' in D.J.C. van Wyk (red.), 20ste eeu Hervormde Teologie, pp. 11-27, SENTIK, Pretoria.

Van Aarde, A.G., 2001, 'The 'cause of Jesus' (Sache Jesu) as the Canon behind the Canon', HTS Teologiese Studies/Theological Studies 57(1\&2), 148-171.

Van Aarde, A.G., 2002, 'Methods and models in the quest for the historial Jesus: Historical criticism and/or social criticism', HTS Teologiese Studies/Theological Studies 58(2), 419-439.

Van Huyssteen, J.W., 2006, Alone in the world? Human uniqueness in science and theology (The Gifford Lectures), William B. Eerdmans Publishing Company, Grand Rapids.

Vos, C.J.A., 1996, Die volheid daarvan 1: Homiletiek uit'n hermeneutieskommunikatiewe perspektief, Raad vir Geestesnavorsing, Pretoria.

Woods, C.J., 1996, Congregational megatrends, Alban Institute, New York. 